\title{
MAGYAROK A MARSON - ALKALMAZOTT MÉRNÖKI TUDOMÁNYOK VERSENYÉNEK KONCEPCIÓJA ÉS EREDMÉNYEI
}

\author{
Pintér Judit Mária \\ tudományos fömunkatárs, Automatizálási és Infokommunikációs Intézet \\ 3515 Miskolc, Miskolc-Egyetemváros, e-mail: pinterjm@uni-miskolc.hu
}

\begin{abstract}
Absztrakt
Az Alkalmazott Mérnöki Tudományok Országos Robotversenye, avagy másnéven a Magyarok a Marson 2006-ban került elöször megszervezésre. A verseny alapitója és a kezdetek óta a kreatív feladatok megalkotója Sipos Attila villamosmérnök, aki magánszemélyként is 14 éve példaképként szolgál a hallgatók számára. 2016 óta a Miskolci Egyetem vált a szakmai verseny befogadó intézményévé. A publikáció az elmúlt 4 év közös munkáját hivatott bemutatni, annak tapasztalatait, sikereit és hosszútávú eredményeit.
\end{abstract}

Kulcsszavak: beágyazott rendszerek, robotika, hallgatói verseny, IoT

\section{Abstract}

The National Robotics Competition in Applied Engineering, also known as the Hungarians on Mars, was first organized in 2006. The founder of the competition and the creator of the creative tasks since the beginning is Attila Sipos, an electrical engineer, who is a role model for students for 14 years. Since 2016, the University of Miskolc has become the host institution of the professional competition. The publication is intended to present the joint work of the last 4 years, its experiences, successes and long-term results.

Keywords: embedded systems, robotics, student competition, IoT

\section{Bevezetés}

„Az Első Magyar Alkalmazott Tudományok Versenye Kiskunhalason szakmai verseny volt. Nem terminátorok küzdöttek egymás ellen, ahogy biztos el lehetne adni a rendezvényt, hanem fiatalok által három hónap alatt elkészitett robotok próbálkoztak a kitüzött feladatot megoldani. A kezdetek kezdetén az én szándékom az volt, hogy valami olyan dolog alkotására ösztönözzem a fiatalokat, ami a gyakorlatban is müködik. [1]"

Ezeket a sorokat tette közzé Sipos Attila 2006-ban az első megszervezett verseny sikeres lebonyolítása után a verseny honlapján. Az immáron 14 éve tartó versenysorozat célja, hogy a diákok megismerjék az alkotás és a csapatmunka örömét, és az eddigi tanulmányaik gyakorlati tapasztalással egészüljenek ki. A verseny az évek során országos méretüvé nőtte ki magát, és aki még anno hallgatóként vett részt a versenyen, most tapasztalt végzett mérnökként ugyanúgy megméretteti magát. Nem csak egyetemi hallgatók kapnak lehetőséget, hanem középiskolás és általános iskolás csapatok is ugyanúgy bemutathatták elkészült robotjaikat. A verseny az évek során több befogadó helyen került megrendezésre, majd 2016 óta a Miskolci Egyetem ad otthont a rendezvénynek. 


\section{A verseny koncepciója}

Minden évben a verseny feladata egy történetbe volt beleszőve ikonikus sci-fi alkotásokkal a föszerepben. A kitüzött feladat elvégzéséhez kellett minden csapatnak 1-1 robotot építenie. A feladattól függően, hol légpárnást, hol kétéltüt, gömbrobotot vagy sziklákkal teli terepen közlekedő járművet kellett építeniük. A küzdelem mindig egy 8 x 8 méteres gondosan megtervezett és megépített pályán zajlott, ahol egyszerre 4 csapat mérkőzött meg egymással. A csapatokat egy program sorsolta négyes csoportba. Egy küldetés ideje 15 perc volt. A nap folyamán, a versenyen elindult csapatok száma alapján egy csapat akár 3-6 alkalommal is összemérhette technológiája fejlettségét a többiekkel. Az első kör után (minden csapat elindult a pályán egyszer) a legtöbb pontot elért csapat a legkevesebb pontot elérő csapattal és a ponttáblázat számtani közepén elhelyezkedő 2 csapattal került össze. A második legtöbb pontot elérö a második legkevesebb pontot szerzett csapattal plusz a ponttáblázat közepéről +2 csapat és így tovább. Hasonló pontszám esetén a csapat nevének abc sorrendje döntött. Három forduló után a 8 legtöbb pontot elért csapat külön döntőt vívott a győzelemért. Előfordulhatott, hogy egy csapatnak egymás után kellett pályára lépnie így a robot energiaellátását erre az esetre kellett méretezniük vagy gondoskodniuk a tartalék akkumulátorról. A megszerzett pontok folyamatosan összeadódtak így a döntőbe jutott csapatok extra pontokat szerezhettek. A robotok elhelyezésére és felkészítésére a mérkőzés előtt 5 perc állt rendelkezésre. Aki nem tudott elindulni a forduló végéig próbálkozhatott. A nap folyamán végig lehetett barkácsolni, programozni, módosítani a roboton.

A körmérkőzések során megszerzett pontszámok alapján született meg a sorrend. A csapatok nyereményét egy díjalap képezte, amit magánszemélyek és cégek felajánlásaiból állt. Az összeg a pontok arányában oszlott el az összes csapat között, így senki sem tért haza üres kézzel. A verseny feladatán és annak lebonyolításán túl az eseménynek sajátságos atmoszférája is van. A megmérettetés már a hivatalos verseny előző napján megkezdődik, mikor a helyszínen a csapatok már a megépített pályán tesztelhetik robotjaikat, vagy éppen akkor végzik az utolsó simításokat. Ez rendszerint eltartott egész éjszaka egészen a verseny kezdetéig. A hivatalos megmérettetés és az eredményhirdetés után egy közös fözéssel zártuk a 2 napot, ahol tapasztalatok, vélemények és szakmai "titkok" cseréltek gazdát.

\section{A Miskolci Egyetem szerepe a verseny szervezésében}

A Miskolci Egyetem hallgatói és oktatói 2015-ben kapták meg a lehetőséget, hogy az akkori versenyen nem csak, mint versenyzők vegyenek részt, hanem, mint megfigyelök is, mert 2016-ban a Miskolci Egyetem lett a befogadó intézmény. A verseny sikerét követően Sipos Attilával és Vizi Pál Gáborral (a verseny másik főszervezője és örökös zsủritagja) úgy döntöttünk, hogy a továbbiakban Miskolcon kerül megrendezésre a verseny minden évben. Azóta 3 sikeresen megrendezett versenyen vagyunk túl és várjuk, hogy a jelenlegi pandémia után végre megrendezhessük a már több mint 1 éve húzódó 14. Magyarok a Marsont. Az alábbi alfejezetek az elmúlt évek feladatait és annak sikereit mutatják be röviden.

\subsection{Magyarok a Marson versenyfeladata}

2016-ban a pálya egy $8 \times 8$ méteres $20 \mathrm{~cm}$ magas palánkkal határolt terület volt, rajta 15 darab 1 méter magas és $16 \mathrm{~cm}$ átmérőjü hengerrel (1. ábra). A hengerek alján egy $3 \mathrm{~cm}$-es és $3 \mathrm{~mm}$ vastag gyürü segítette a rögzítést. Minden oszlop tetején volt egy optikai kód és három rés 120 fokban körben. Amiben az oszlopok egyediek voltak, az a pontszámtól függően a rés magassága. Minden rés körül volt egy $2 \mathrm{~cm}$-es fehér gyürü és $1 \mathrm{~cm}$-re a rés pereme felett középpontban egy $5 \mathrm{~mm}$-es LTE5208AC infra led. A led $250 \mathrm{~Hz}$-es 10\% kitöltési tényezőjü impulzusokat bocsájtott ki. Az optikai kód egy min- 
tázat, amiröl készült egy táblázat és a versenyzők még a verseny előtt megkapták. A célterület tetején volt a kódleolvasó és egy LED-es jelzőrendszer, így mindig tudtuk, mely csapaté az utolsó átkódolás.

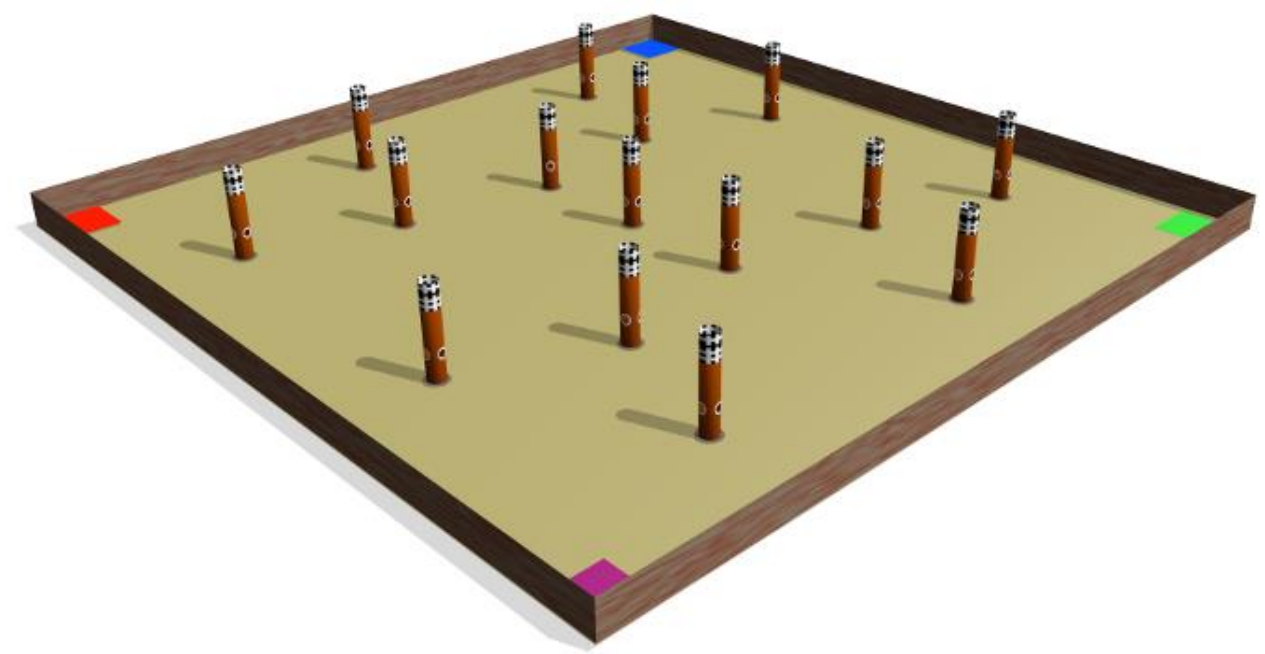

\section{1. ábra. A 2016-os versenypálya 3D terve}

A robotnak saját energiaforrással kellett rendelkeznie. Súlya nem haladhatta meg az 5 kg-ot. Egy $30 \mathrm{~cm}$ átméröjü és $60 \mathrm{~cm}$ magas hengerbe bele kellett férnie, kivételt az aktív robotkar jelentett.

A jeladót a henger belsejébe juttató kar 10 másodpercig lehetett kint a robot (henger) síkjából. A robotkar hossza jeladó nélkül $20 \mathrm{~cm}$ lehetett maximum. A meghajtás módja nem volt korlátozva.

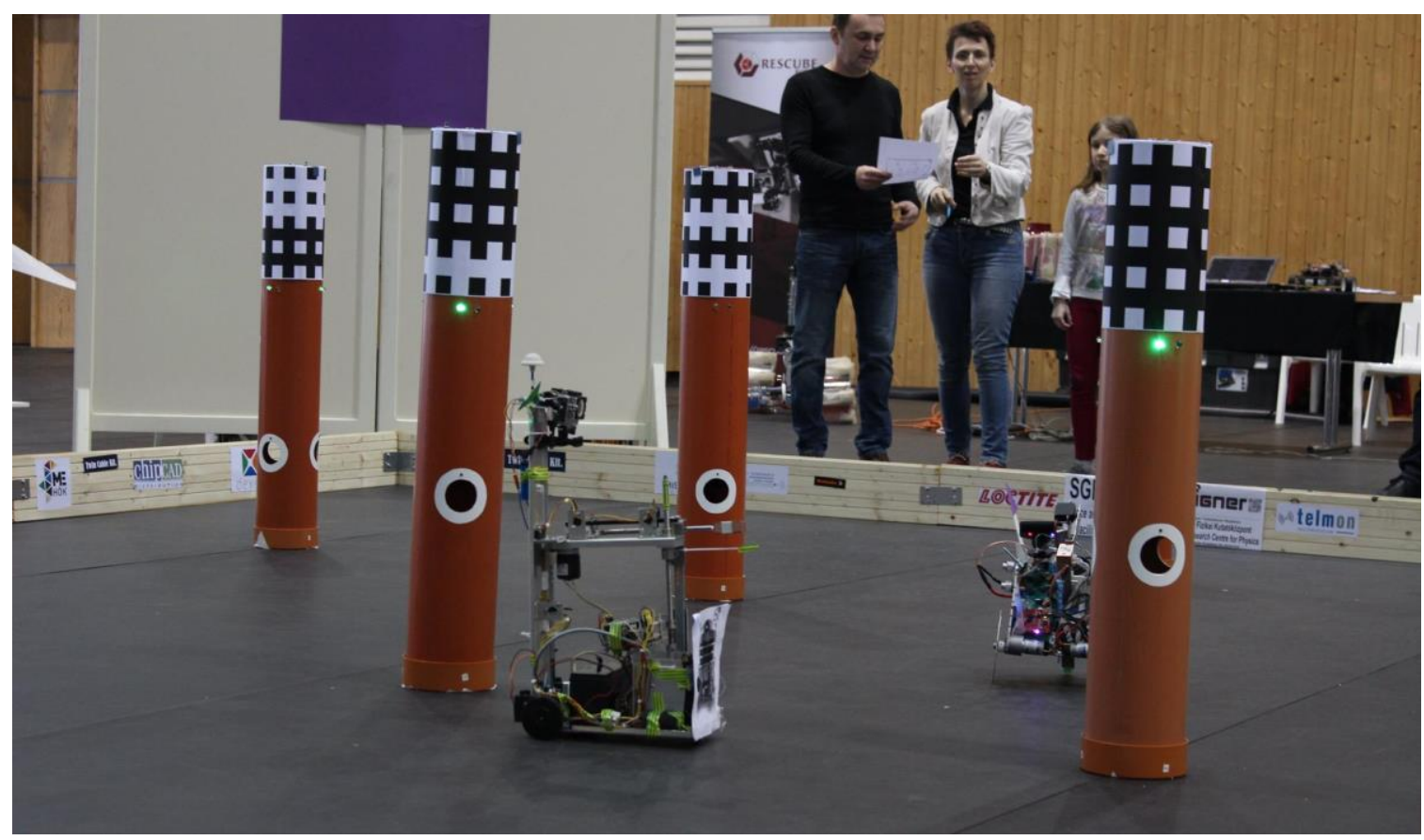

2. ábra. Robotok verseny közben 
A robot irányítása valós idejủ volt. Az irányítás bármilyen saját építésủ eszközzel engedélyezett volt. Ami mégis különlegessé tette a feladatot az az, hogy a csapat csak a roboton elhelyezett kamerák képét láthatta. Egy paraván takarta el a pályát azon kíváncsi szemek elől, akik a pálya sarkainál elhelyezett asztaloknál ülve irányították robotokat. A 2. ábra éppen egy körmérkőzés pillanatát mutatja be, ahol jól látszanak a szabályoknak eleget tevő robotok és a célterületek.

\subsection{Magyarok a Marson versenyfeladata}

2017-ben a pálya a hagyományokhoz hüen 8 x 8 méteres volt. A pálya széle $20 \mathrm{~cm}$ magas, míg a belső elválasztók $10 \mathrm{~cm}$ magas palánkok voltak. A pályán minden rés és palánkok közötti távolság egységesen $28 \mathrm{~cm}$ volt. A robot maximum $25 \mathrm{~cm}$ átmérójü GÖMB lehetett, melynek felülete $+/-2$ milliméterrel térhetett el a gömb matematikai definíciójától. Súlya nem lehetett több 3 kg-nál.

Igazi mágusokhoz illően valós időben egy "varázspálcával" kellett megvalósítani a robot vezérlését. A pálcának bele kellett férnie egy $35 \mathrm{~mm}$ átmérőjü és $50 \mathrm{~cm}$ hosszú hengerbe. A varázspálcán az egyetlen bemenet egy nyomógomb lehetett, visszajelzésként, pedig bármi, ami elfért a pálcán.

A vezérlőnek önálló táplálásúnak kellett lennie és semmiféle vezetékes kapcsolattal nem rendelkezhetett. A csapatok a pálya saját színü sarkát használhatták, nem lehetett körbejárva a robotot követni.

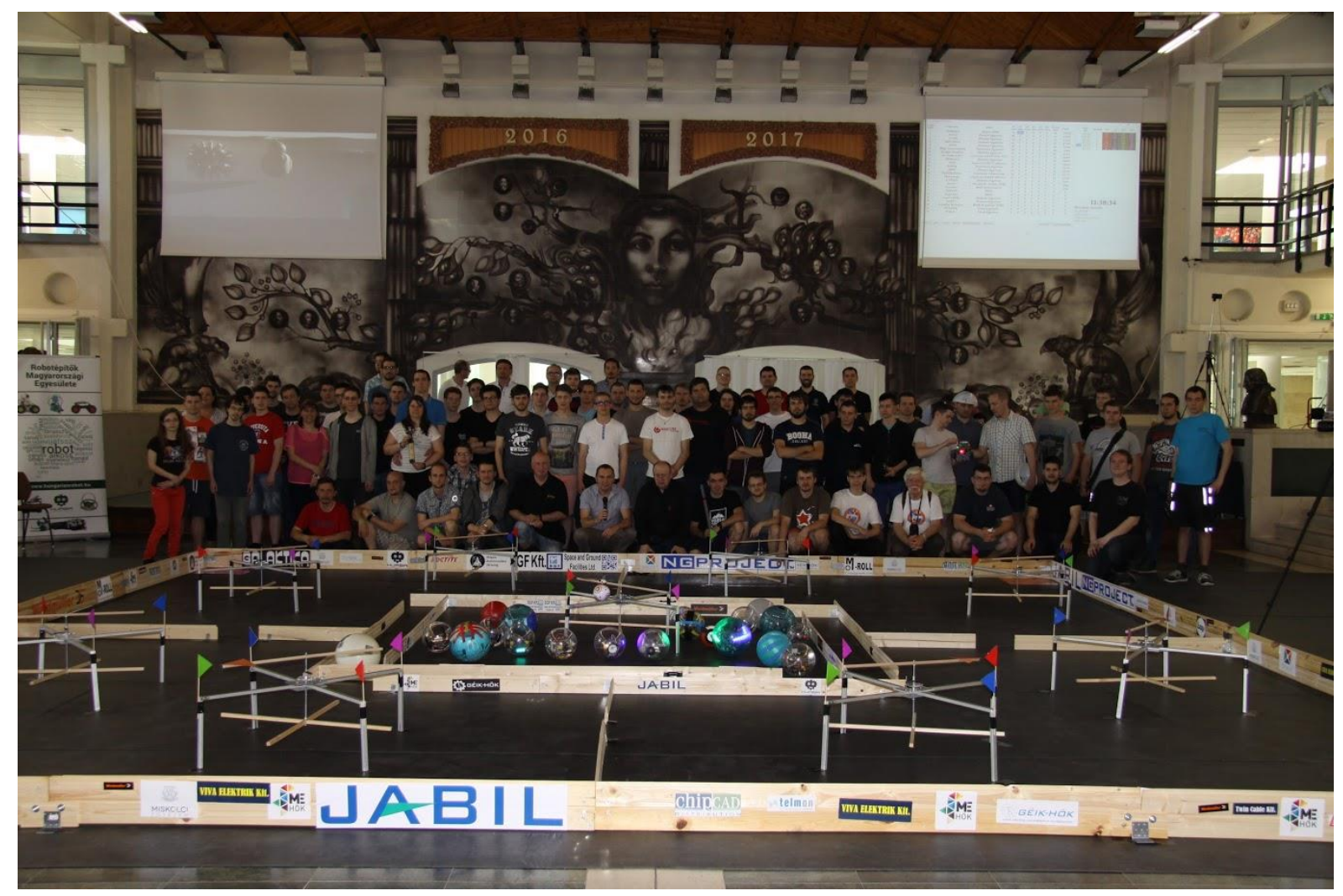

3. ábra. A 2017-es verseny csoportképe

A pályán (3. ábra) összesen 9 aréna helyezkedett el. Az aréna összesen 5 állapotot vehetett fel. A nyíl mutathatott a négy szín valamelyikére, illetve a színek közti semleges területre. A nyíl egyértel- 
müen és stabilan állt be a színes zászló irányába. A karok mozgatása nem igényelt erőkifejtést. A karok és a nyíl egymáshoz viszonyított pozíciója arénánként eltérő lehetett. Pontszerzésnek csak az volt tekinthető, ha a nyíl stabilan megállt a zászló irányában. Amennyiben csak úgy átlendült a stabil helyzeten, akkor az csak egy lelkes próbálkozás volt. A küldetések alatt minden csapatot önkéntes versenybírók követtek, ök jelezték az érvényes pontokat.

\subsection{Magyarok a Marson versenyfeladata}

A résztvevő csapatoknak 2018-ban az idő volt a legnagyobb ellenfelük, mivel 24 óra állt a rendelkezésükre, hogy megépítsenek egy robotot, aminek egy terep pályán kellett megállnia a helyét. A robot megépítéséhez szükséges alapvető alkatrészeket az első 20 csapatnak - akik hivatalosan is benyújtották jelentkezésüket - a Miskolci Egyetem biztosította. A csomagból azonban nem lehetett a robotot 100 \%-osra megépíteni.

A pálya megszokottan 8 x 8 méteres volt. A központi terület dombos felület volt. Nagyobb sziklák tagolták, amik akár $12 \mathrm{~cm}$ magasak is lehettek. A központi területre egy 16 fokos emelkedön lehetett bejutni. A fennmaradó területet $28 \mathrm{~mm}$ magas és $50 \mathrm{~mm}$ széles különböző hosszúságú tetőlécek szabdalták. A célterületekhez ezeken átgázolva, illetve a labirintust követve is el lehetett jutni.

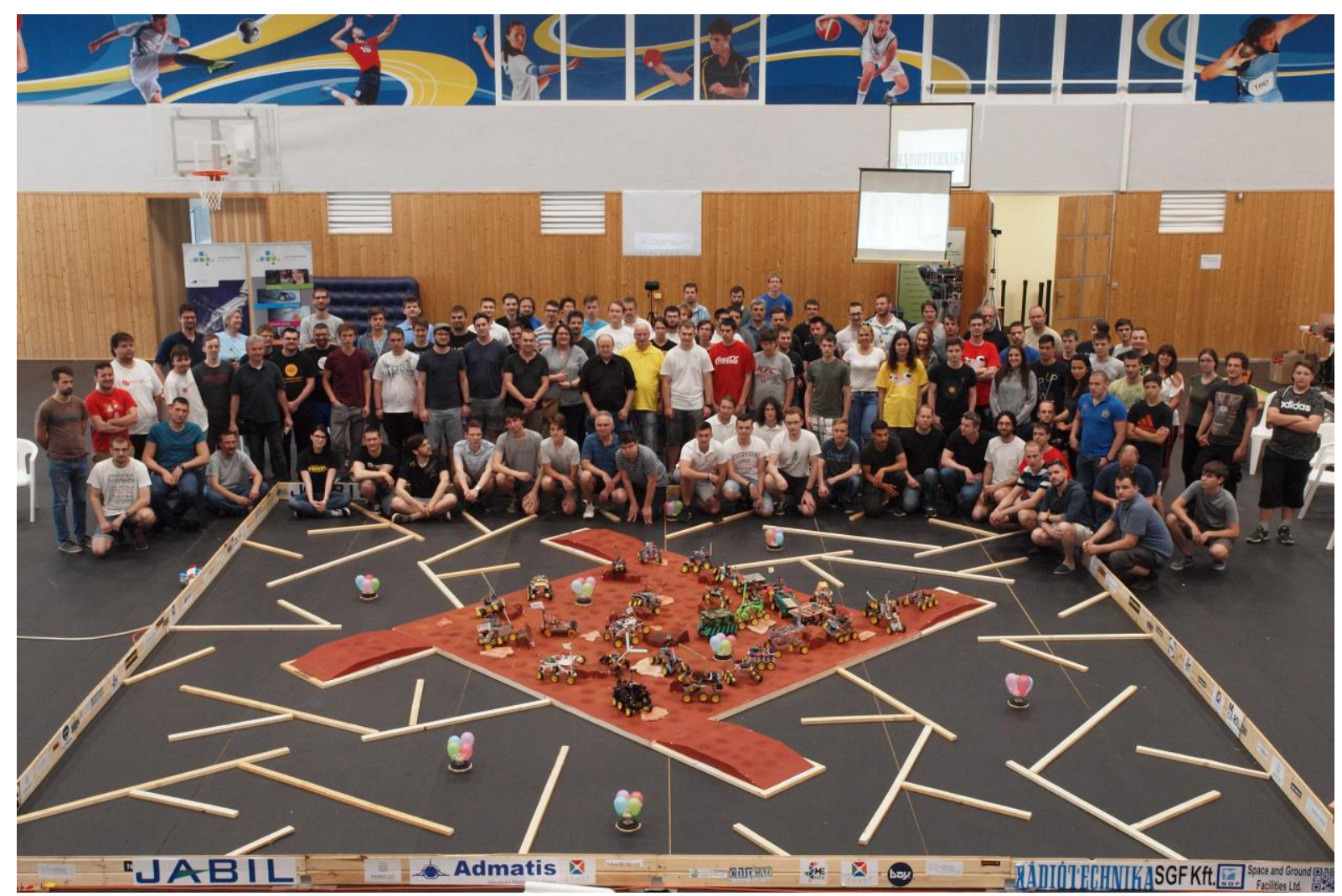

4. ábra. 13. Magyarok a Marson csoportkép

A pontszerzéshez a képen (4. ábra) is látható célterületeken elhelyezett csapat színével megegyező $8 \mathrm{~cm}$ átméröjü lufikat kellett $1 \mathrm{db}$ rajzszeggel felrobbantani. A célterületek különbözö magasságban voltak, így a robotra fixen felszerelt tủvel nem lehetett minden pontot bezsebelni. Az idő és a célterü- 
letek azonos súllyal számítottak a pontokba. Minden lufi 90 pontot és minden megmaradt másodperc 1 pontot ért. Ha valaki elvétette és egy másik csapat lufiját durrantotta ki, vissza kellett vinnie a robotot a kiindulási pontra, a szervezők pedig pótolták a lufit. A megmaradt másodperceket mind a nyolc céltárgy begyüjtésével, majd a robot visszanavigálásával a kiindulási helyre lehetett pontra váltani.

\subsection{Magyarok a Marson versenyfeladata}

A 14. Magyarok a Marson verseny eredetileg 2019-ben került volna megszervezésre, de a feladat nehézsége miatt a szervezők a csapatokkal egyetértésben úgy döntöttek, hogy 2020 tavaszára helyezik át a versenyt. Sajnos az idén a pandémia miatt újból kétszer el kellett halasztanunk a versenyt, de továbbra sem tettünk le arról, hogy megszervezzük, hiszen több csapat is már kész robotokkal várja a mérkőzést és a találkozót.

Így a jövő évi verseny a következő küldetést tüzte ki célul: egy 8 × 8 méteres pályán a négy célterület $2 \mathrm{~cm}$ vastag xps lemez, mérete $120 \times 125 \mathrm{~cm}$ (5. ábra). A központi területen helyezkednek el a viszszatérö ürhajók. A pályát $30 \mathrm{~mm}$ magas és $50 \mathrm{~mm}$ széles különböző hosszúságú tetőlécek szabdalják.

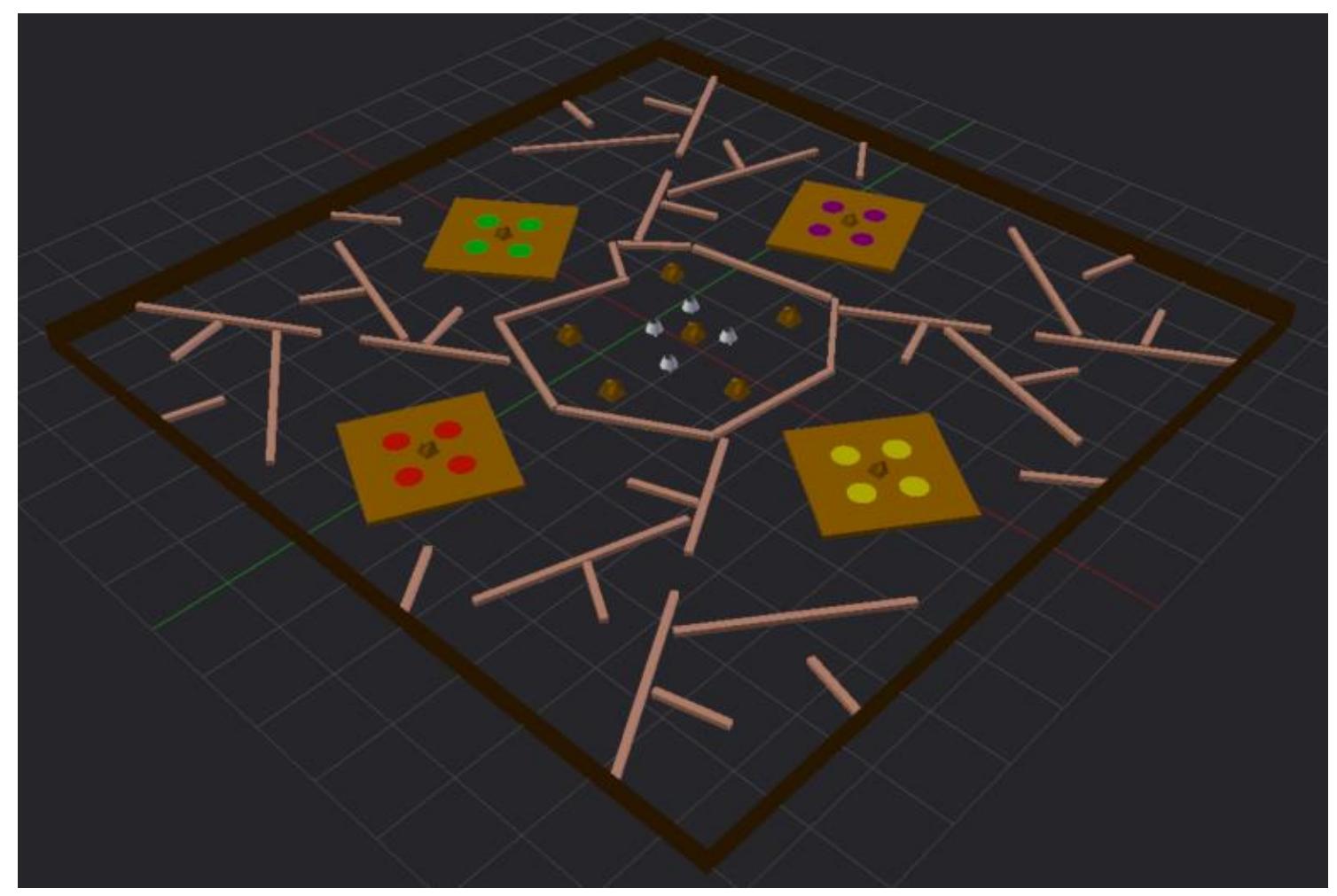

5. ábra. A következö küldetés 3D pályaterve

A 3D nyomtatás olyan szintủ szabadságot ad az alkotás folyamatában, amit egyszerüen kötelező ismerni a mi világunkban. Napjainkban rakétákat nyomtatnak, így mi sem maradhatunk le, ezért a robot összes mechanikai elemét 3D nyomtatni kell. Kivételt képez a $3 \mathrm{~mm}$-es vagy kisebb és $40 \mathrm{~mm}$ vagy rövidebb csavar a hozzávaló alátéttel és anyával. A marsi konyhában szintén található még befőttesgumi, kétoldalas ragasztó, szigetelőszalag, gyorskötöző, mágnes, pillanat és egyéb ragasztók de más nem. Ha kell egy rugó, vagy csak egy egyszerü rudacska, akkor azt nyomtatni kell. A filament 
anyaga bármilyen lehet. Az elektronika PCB nem lehet mechanikai szerkezeti elem. A roboton két fajta mechanikai mozgásra képes szerkezet lehet korlátlan számban, ami azt is jelenti, hogy a verseny alatt bármikor cserélhetőek.

A robot elektronikája, energiaellátása szabadon választható. A robotnak természetesen távirányításúnak és önálló energiaellátásúnak kell lennie. Mérete nem lehet nagyobb 30 x 30 x $30 \mathrm{~cm}$-nél. A robot irányítása valós idejü, a 2018-as versenyen bemutatkozott vezérlőpult segítségével, amit a szervezők biztosítanak. A konzolból egy tíz eres szalagkábel jön ki, ami egy 2 x 5 PFL-10 csatlakozóban végződik. A kapcsolási rajz letölthető a verseny oldaláról.

A pályán négy azonos felépítésủ célterület található. A $2 \mathrm{~cm}$ magas területen négy-négy $20 \mathrm{~cm}$ átméröjü kerek lyuk található, melyeket $6 \mathrm{~mm}$-es airsoft BB lövedékekkel töltünk fel (5. ábra). Ebböl kell minimum 1 darabot felvenni.

Egy célterületen azonos színủ golyók vannak, teljesen mindegy melyik lyukból vesszük a mintát. Azért van ezekből négy, hogy akár az összes robot egyidőben egy célterületen is hozzáférjen a mintához. A négy célterületen különböző színüek a lövedékek, ahogy azt az 5. ábra 3D pályarajza is mutatja. A központi terület a küldetés végállomása. Az itt leszállt négy ürhajó egyikébe (6. ábra) kell bejuttatni a mintákat és extra pontokért Mark Watney-t is (szintén 3D nyomtatott lesz).

A mintákkal és Markkal együtt a robot bármely alkatrésze bekerülhet az ürhajóba. Ami a lényeg a minták és Mark 100\%-ban a hajóban legyen. A talajhoz rögzített ürhajó $105 \mathrm{~mm}$ magas, $109 \mathrm{~mm}$ széles és a tetején $56 \mathrm{~mm}$ átméröjü a lyuk. Mark Watney aktuális küldetése úgy tünik nem várt hosszúra nyúlik, de reméljük újból sikeresen zárul és lassan tervezhetjük a következőt.

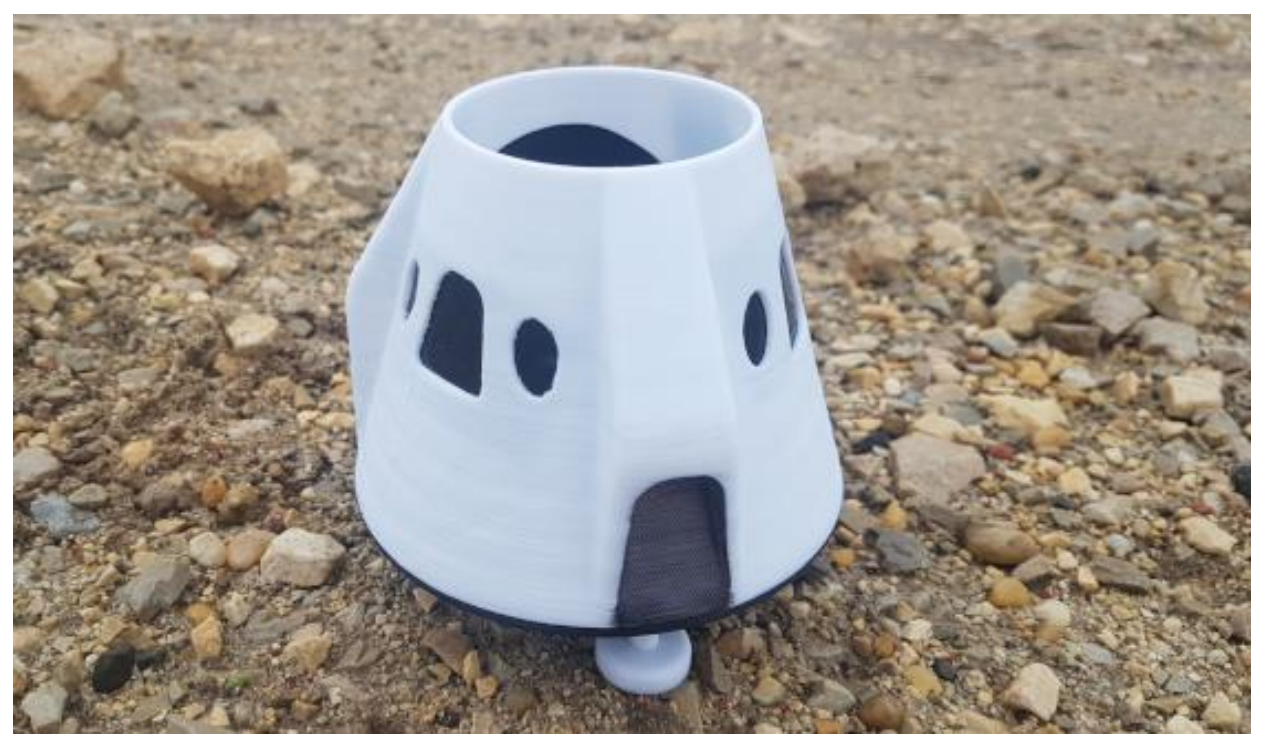

6. ábra. A központi területen elhelyezett visszatérö ürhajó mintája

\section{4 Összefoglalás}

Az elmúlt éveket tekintve rengeteg tapasztalatot szereztek a hallgatók és mi magunk, szervezők is. Nem csak a robotok megtervezése jelentett kihívást, hanem a pályatervezés és megvalósítás, valamint a szervezés, kiemelten pedig a szponzorációs tevékenyégek. Nagyon hálásak vagyunk minden évben, hogy a támogató cégek és magánszemélyek révén plusz motivációként tudjuk feltüntetni a díjalapot és minden évben kapuk tárgyi felajánlásokat, így lehetőségünk nyílik különdíjak adományozására is. 
A rendezvény nem csak egy szimpla versenyként müködik, hanem az évek során egy közösség formálódott, amelynek évi rendszeres találkozójává vált. Az évek alatt ez a közösség folyamatosan fejlődik, ahol a szakma szeretete volt mindig is a középpontban.

A hallgatók számára jelentős szakmai tapasztalat megszerzésére nyílt lehetőség minden alkalommal. A Miskolci Egyetem számára, ezen belül az Automatizálási és Infokommunikációs Intézet számára kiemelt fontosságú, hiszen a verseny tanulmányi szempontból is kiemelt helyet kapott. Az elmúlt években közel 200 versenyző vett részt a versenyen (ipari szakemberek, egyetemi hallgatók, középiskolai diákok, általános iskolások), melyek közül 48 a Miskolci Egyetemet képviselte. Az elmúlt 4 évben 12 TDK dolgozat 9 publikáció és több szakdolgozat is született a témában, az elkészült robotok pedig a gyakorlati órákon és egyetemi nyílt rendezvényeken kerülnek bemutatásra.

\section{Köszönetnyilvánítás}

A cikkben ismertetett kutató munka az EFOP-3.6.1-16-2016-00011 jelü „Fiatalodó és Megújuló Egyetem - Innovatív Tudásváros - a Miskolci Egyetem intelligens szakosodást szolgáló intézményi fejlesztése" projekt részeként - a Széchenyi 2020 keretében - az Európai Unió támogatásával, az Európai Szociális Alap társfinanszírozásával valósul meg.

\section{IRODALOMJEGYZÉK}

[1] http://www.magyarokamarson.hu 